\title{
Curtain color and lighting program in broiler production: I - general performance
}

\author{
Valéria Maria Nascimento Abreu ${ }^{1}$, Paulo Giovanni de Abreu ${ }^{1}$, Arlei Coldebella ${ }^{1}$, Fátima \\ Regina Ferreira Jaenisch ${ }^{1}$, Jonas Irineu dos Santos Filho ${ }^{1}$, Doralice Pedroso de Paiva ${ }^{1}$
}

${ }^{1}$ Embrapa Suínos e Aves, BR 153, km 110, Caixa Postal 21 - 89700-000, Concórdia, Santa Catarina, Brazil.

ABSTRACT - The objective of the present study was to evaluate mortality and performance, darkling beetle population (Alphitobius diaperinus), light intensity, electrical energy consumption and economic efficiency of broilers reared under two lighting programs (nearly continuous or intermittent) and two curtain colors (yellow or blue). The experiment was conducted between June, 2004 and May, 2005. Six flocks were sequentially housed in four $12 \times 10 \mathrm{~m}$ broiler houses divided into 4 pens with 200 birds each. Litter was reused six times or until flock 6. Body weight and feed conversion were determined on days 21, 35, and 42 of each flock. Mortality was recorded daily. Electrical energy consumption was recorded at the end of the grow-out of each flock (every 42 days). A completely randomized design in a $6 \times 2 \times 2$ factorial arrangement (flocks, lighting programs, curtains) with four replicates per treatment was applied. Broilers reared in houses with yellow curtains and under nearly continuous lighting programs presented the best feed conversion ratio and the highest body weight. Nearly continuous lighting programs resulted in 1.48 times more sudden deaths and 1.34 times higher general mortality when compared with intermittent lighting programs. Electrical energy consumption was 2.12 times higher in nearly continuous lighting programs in relation to intermittent lighting programs. The presence of darkling beetles was higher in broiler houses with blue curtains and intermittent lighting program. The economic analysis showed the feasibility of using a mixed system, with intermittent light program in winter and spring and nearly continuous lighting program in the summer and autumn, both in broiler houses with yellow curtains.

Key Words: Alphitobius diaperinus, economic analysis, electric energy, intermittent, lighting intensity, semi-continuous

\section{Introduction}

The objective of lighting programs is to regulate feed intake. Genetics, management practices, feed nutrient density, and feed intake should be taken into account when defining lighting programs for broilers (Fussel et al., 2003). According to these authors, season and latitude where the broiler houses are located should also be considered, as they interfere with day length. Types of poultry house affect lighting programs. For instance, controlled environments, such as those provided by dark houses, allow controlling lighting period during the 24 hours of the day, whereas open-sided broiler houses are subject to natural day length. According to Rutz \& Bermudez (2004), regardless of house type, the principles and essential objectives of lighting programs for broilers are the same.

Different lighting schemes (continuous or intermittent) and different light intensities have been proposed to promote higher weight gain, better feed conversion ratio and carcass quality, with no metabolic changes (Rutz et al.,
2000). Continuous photoperiods include continuous (24Light:0Dark) and nearly continuous (23Light:1Dark, 16Light:8Dark) lighting programs. Long duration continuous lighting programs allow consistent access to feed during the entire day, resulting in maximum feed intake and weight gain by stimulating feed intake during regular periods. Intermittent lighting synchronizes better feed intake with feed passage through the digestive tract of broilers (Rutz \& Bermudez, 2004). Moraes et al. (2007) studied the effect of lighting programs on the feeding behavior of broilers and concluded that feed intake varies according to light availability.

In addition to lighting programs, broiler house curtains are also essential in broiler production. The use of yellow or blue curtains has been discussed in industrial poultry production. There is little scientific information on the effect of curtain color on broiler performance. It is also discussed if curtain color could affect the darkling beetle population in broiler houses, by attracting or repelling it. The objective of this study was to evaluate broiler performance and mortality, darkling beetle population, lighting level, 
electric power consumption, and the economic efficiency of broiler houses equipped with yellow or blue curtains and two lighting programs (nearly continuous and intermittent).

\section{Material and Methods}

This experiment was carried out at Embrapa Suínos e Aves, Brazil, between June 24, 2004 and May 12, 2005. Six consecutive broiler flocks were reared in four broiler houses measuring $12 \mathrm{~m} \times 10 \mathrm{~m}$, internally divided into four pens housing 200 birds each.

A total of 19,200 Ross males was distributed according to a completely randomized experimental design in a $6 \times 2 \times 2$ factorial arrangement [six flocks, two lighting programs (nearly continuous or intermittent) and two curtain colors (yellow or blue)], with four replicates per treatment. The first flock was housed on a new litter, which was reused by the subsequent flocks. Litter was replaced only in the brooding area. Light was provided by $60 \mathrm{~W}$ incandescent light bulbs. Birds were distributed according to the following combinations of lighting programs (nearly continuous = 23L:1D; intermittent: $16 \mathrm{~L}: 2 \mathrm{D}+1 \mathrm{~L}+2 \mathrm{D}$, where $\mathrm{L}=$ hours of light and $\mathrm{D}=$ hours of dark) with curtain color (yellow or blue): house 1 = blue curtain and intermittent light; house 2 = yellow curtain and intermittent light; house 3 = yellow curtain and nearly continuous light; house 4 = blue curtain and nearly continuous light.

Birds and feeds were weighed weekly, and the following parameters were evaluated: live weight, weight gain, feed intake and feed conversion ratio of broilers at 21, 35 and 42 days of age. Mortality was daily recorded and classified as ascitis, sudden death, or other causes. Total mortality was also analyzed. Electric power consumption was also recorded at flock housing and removal. Light intensity (in lux) received by birds was measured using a lux meter.

Performance data were analyzed considering the average results applying the theory of mixed models, using the effects of flock, curtain, light, age and their interactions and 15 variance and covariance matrix structures analyzed by the MIXED procedure of SAS statistical package (SAS Institute Inc., 2003), according to Xavier's proposal (2000). The covariance matrix was chosen based on the Akaike information criterion (AIC). Mortality was analyzed by logistic regression, considering the effects of flock, light, curtain and their interactions.

Darkling beetle (Alphitobius diaperinus) population was evaluated by collecting three litter sub-samples per pen, considering three sub-habitats, as described by Safrit \& Axtel (1984): close to the wall, below a tube feeder, and in an open area, between waterer and feeder lines. Three collections were performed per flock: before housing, when the flock was 20 days of age, and immediately before flock removal. Samples were taken using a $10 \mathrm{~cm}$ long $\times 5 \mathrm{~cm}$ wide PVC tube vertically inserted in the litter by rotational movements. The three sub-samples were pooled in a single flask. In the laboratory, insects were identified and counted. Considering the presence of other species neglectable, only A. diaperinus adults and larvae (more than $1 \mathrm{~mm}$ long, visible by naked eye) were counted and preserved in $70 \%$ alcohol. Data on darkling beetle population were submitted to analysis of variance according to a completely randomized experimental design in split plots, with the curtain and light effects associated to the plot, effecrs of flock to the subplot, and effects of collection to the sub-subplot. Data were $\log (y+1)$ transformed for analysis.

Economic evaluation was done by calculating the production cost according to the methodology described by Santos Filho et al. (1999) and Canever et al. (1996). The Monte Carlo method of simulation was applied. The following random parameters were used: prices of corn and soybean meal, feed intake during the starting, growing, and finishing phases, and market weight. Corn and soybean meal prices were estimated as the average wholesale prices paid in the last five years. As the results are expressed in terms of possibilities, the choice took into consideration the three assumptions of decision-making under risk conditions (Resende Filho et al., 2000).

\section{Results and Discussion}

Feed conversion ratio and feed intake data were analyzed according to a variance and covariance matrix of first antedependence type, whereas live weight analysis used a non-structured matrix, both based on AIC value. There was a significant effect of the interaction $\times$ light $\times$ curtain $\times$ flock on all parameters studied (Table 1).

When discussing bird performance, the difference in parameters related to the season when broilers were reared must be mentioned (Table 2). Flock 1 was reared during winter (temperature ranging between 4.4 and $30.4^{\circ} \mathrm{C}$ ), flock 2 during winter and beginning of spring (temperature ranging between 4.5 and $40.2^{\circ} \mathrm{C}$ ), flock 3 during spring (temperature ranging between 8.4 and $34.8^{\circ} \mathrm{C}$ ), flock 4 during the end of spring and beginning of summer (temperature ranging between 12.6 and $37.1^{\circ} \mathrm{C}$ ), flock 5 during summer (temperature ranging between 13.8 and $38.0^{\circ} \mathrm{C}$ ), and flock 6 during fall (temperature ranging between 9.6 and $34.5^{\circ} \mathrm{C}$ ). This is relevant, because the broiler houses used in this study were 
Table 1 - Summary of the analyses of variance of live weight, feed intake and feed conversion ratio

\begin{tabular}{|c|c|c|c|c|}
\hline Source & $\mathrm{DF}^{4}$ & ${\text { Live } \text { weight }^{1}}^{1}$ & Feed intake ${ }^{2}$ & Feed conversion ratio $^{3}$ \\
\hline Flock & 5 & $<0.0001$ & $<0.0001$ & $<0.0001$ \\
\hline Light & 1 & 0.0033 & 0.4511 & 0.0194 \\
\hline Light $\times$ flock & 5 & 0.0017 & 0.5809 & $<0.0001$ \\
\hline Curtain & 1 & $<0.0001$ & 0.0015 & 0.0014 \\
\hline Curtain $\times$ flock & 5 & 0.2402 & 0.3119 & 0.6026 \\
\hline Light $\times$ curtain & 1 & 0.9247 & 0.9610 & 0.9562 \\
\hline Light $\times$ curtain $\times$ flock & 5 & 0.0247 & $<0.0001$ & $<0.0001$ \\
\hline Age & 2 & $<0.0001$ & $<0.0001$ & $<0.0001$ \\
\hline Age $\times$ flock & 10 & $<0.0001$ & $<0.0001$ & $<0.0001$ \\
\hline Age $\times$ light & 2 & 0.0378 & 0.0016 & 0.0002 \\
\hline Age $\times$ light $\times$ flock & 10 & $<0.0001$ & 0.0432 & $<0.0001$ \\
\hline Age $\times$ curtain & 2 & 0.0002 & 0.4333 & 0.0012 \\
\hline Age $\times$ curtain $\times$ flock & 10 & 0.0045 & 0.5152 & 0.0022 \\
\hline Age $\times$ light $\times$ curtain & 2 & 0.0561 & 0.7314 & 0.0619 \\
\hline Age $\times$ light $\times$ curtain $\times$ flock & 10 & 0.0017 & 0.0403 & $<0.0001$ \\
\hline
\end{tabular}

1 - non-structured; 2 - first antedependence; 3 - first antedependence; 4 - Degrees of freedom.

conventional open-sided houses, and were equipped only with ventilation fans and completely manual curtain management. After birds were 21 days, curtains remained open virtually until birds were removed. Moreover, during the hot seasons, feed withdrawal was used, particularly after week 5 . When morning temperature was around $26-27^{\circ} \mathrm{C}$, feed was withdrawn, and the feeders were filled only in the evening, when temperature was not so high. Temperature ranges were very wide, even during the same grow-out. This demonstrates the challenge of keeping internal house environment within the thermal comfort limits established for broilers rearing, as well as the effort made by birds to maintain body temperature and, at the same time, to grow. According to Abreu \& Abreu (2001), optimal air temperature values are $23^{\circ} \mathrm{C}$ to $26^{\circ} \mathrm{C} ; 20$ to $23^{\circ} \mathrm{C}$ and $20^{\circ} \mathrm{C}$ for four-, five, and six-week-old broilers. The recommended relative humidity is 60 to $70 \%$, regardless of broiler age.

Live weight at 21 days of age in flock 5 was different $(\mathrm{P}<0.05)$ in broilers reared in houses with yellow curtains, where nearly continuous light promoted better live weight, and in flock 6, with the best result obtained with intermittent light. In houses with blue curtains, only flock 6 was different, with nearly continuous light promoting better live weight. Live weight at 21 days is important because at this age, brooding is completely removed. During the coldest months of the year, houses remained longer with the curtains closed, which may explain the higher effect of curtain color. In flock 6, when intermittent light was used, the best live weight results were obtained with the yellow curtain. On the other hand, when nearly continuous light was used, the best results were found in flocks reared with houses with blue curtains.

Feed intake at 21 days was different in flock 2, whose highest values were obtained with the use of nearly continuous light and yellow curtains. In flock 5, feed intake was higher when birds were reared with nearly continuous light and yellow curtains, whereas in flock 6 , birds with nearly continuous light and blue curtains and with intermittent light and yellow curtains presented higher feed intake.

Feed conversion ratio at 21 days presented significant differences only in flock 6, when both yellow and blue curtains promoted better results when lighting was intermittent (1.76), whereas with nearly continuous light, the best feed conversion ratio was found with blue curtains (1.68).

Evaluation at 35 days of age is particularly relevant to assess if growth was not normal, because compensatory growth may happen between 28 and 35 days. According to Zubair \& Lesson (1996), temporary unfavorable growth conditions cause abnormal growth, but when favorable conditions are reestablished, broilers usually present growth acceleration. Therefore, those authors define compensatory growth as abnormal rapid growth.

Live weight of 35-day-old broilers was not influenced by lighting program and/or curtain color only in flock 1 . In flock 2, with the use of intermittent light and nearly continuous light, birds in houses with yellow curtain presented higher live weight. In flock 3 , the best result was found with intermittent light and yellow curtains. In flock 4 , regardless of curtain color, the best response was obtained with nearly continuous light. In flock 5, nearly continuous light and yellow curtains also produced the best results. In flock 6 , regardless of the lighting program, the best live weights were obtained by broilers reared in houses with yellow curtains.

There were significant differences in feed intake at 35 days for flock 3 , where yellow curtains with nearly 
Table 2 - Average live weight, feed intake and feed conversion ratio of each flock according to bird age, lighting program and curtain color

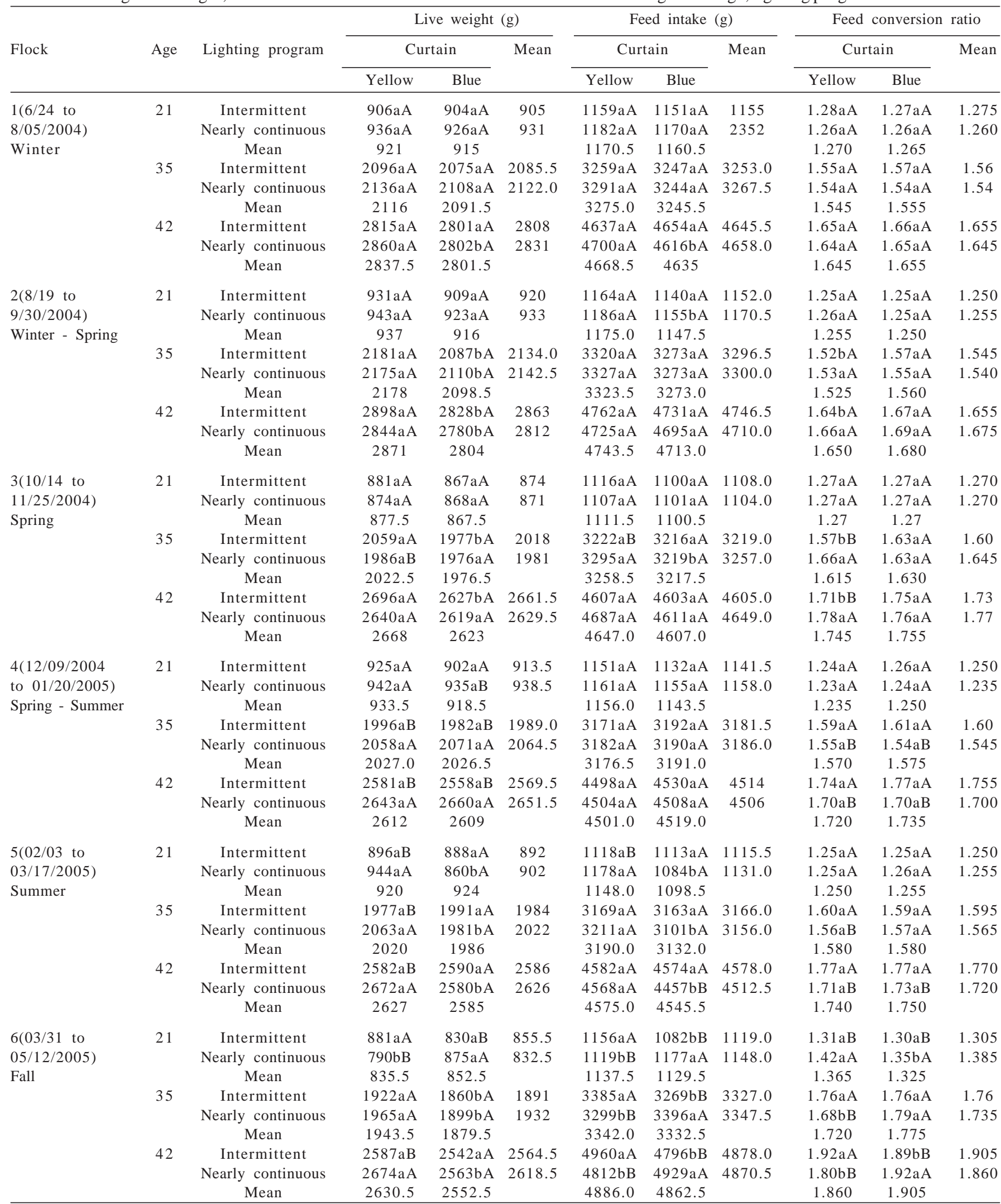

Means followed by different small letters in the same row and different capital letters in the same column are different ( $\mathrm{P} \leq 0.05)$ by F test. 
continuous light promoted the highest feed intake. The same results were obtained in flock 5 . In flock 6, yellow curtains with intermittent light (and vice-versa) and blue curtains with nearly continuous light (and vice-versa) promoted higher feed intake.

In flocks 2 and 3, feed conversion ratio at 35 days was obtained with intermittent light with yellow curtains, whereas in flock 4, regardless of curtain color, nearly continuous light resulted in the best feed conversion ratio. In flocks 5 and 6 , the best results were obtained with yellow curtains and nearly continuous light.

Flocks were removed at 42 days, and therefore, results at this age reflect all the influences to which birds were submitted.

Live weight at 42 days presented significant differences, with the best results obtained in flock 1 with the use of nearly continuous light and yellow curtains; in flock 2, with nearly continuous light and with intermittent light and yellow curtains; in flock 3, with intermittent light and yellow curtains; in flock 4, with yellow curtains and with blue curtains and nearly continuous light; and in flocks 5 and 6 , with yellow curtains and nearly continuous light.

The best feed intake results at 42 days were obtained: in flock 1 , using nearly continuous light and yellow curtains; in flock 5, using blue curtains with intermittent light and nearly continuous light, with yellow curtains; and in flock 6 , the highest feed intake with yellow curtains was obtained with intermittent light, and with blue curtains when nearly continuous light was used. Therefore, the results show that the intermittent lighting program associated with yellow curtains promoted higher feed intake, whereas the highest feed intake with nearly continuous light was obtained when blue curtains were used.

Feed conversion ratio at 42 days was better in flocks 2 and 3 with intermittent light and yellow curtains, and in flocks 4 and 5 with yellow or blue curtains with nearly continuous light. In flock 6 , the best values were obtained with yellow curtains and nearly continuous light or with blue curtain and intermittent light. When intermittent light was used, the best feed conversion ratio was obtained with blue curtains, but for nearly continuous light, the best results were found with yellow curtains.

Live weight and feed conversion ratio were worse as seasons became hotter. In flocks 1, 4, 5 and 6, both live weight and feed conversion ratio were better when yellow curtains were used with nearly continuous lighting program. In flocks 2 and 3, the best results were also obtained with yellow curtains, but with the intermittent lighting program. Flocks 4, 5 and 6 were reared in the hotter seasons, when there is more light during the night, and birds wait for cooler environmental temperatures to feed. These results are partially consistent with the findings of Classen (1992), quoted by Rutz et al. (2000), that continuous lighting programs allow consistent access of the birds to the feed during the whole day, thereby promoting maximum feed intake and weight gain due to feed ingestion stimulation. Buyse et al. (1996) evaluated the live performance of broilers submitted to intermittent (1 hour of light and 3 hours of dark) or nearly continuous (23 hours of light and 1 hour of darkness) lighting programs and showed that, up to 28 days of age, broiler body weight was higher with nearly continuous lighting program, but at 41 days, this difference disappeared and bird performance was similar at both programs. Renden et al. (1996) observed an effect of the lighting program on weight gain, but not on the feed efficiency of 49-day-old broilers submitted to four different lighting programs. Moraes (2007), studying the effect of lighting programs on the feeding behavior of broilers, concluded that feed intake changes according to light availability during a $24 \mathrm{~h}$ period, and that feed intake during the night was higher in broilers under artificial light supplementation, and that birds submitted to a 23-hour photoperiod presented constant feed intake during the 24 hours of the day.

It is assumed that blue curtains promote better performance due to the lower energy expenditure resulting from lower physical activity. However, this may also result in lower performance, because as birds move less, they may not be properly fed. The curtain color results indicate that, in general, broilers reared in houses with yellow curtains had better performance.

Table 3 - Summary of logistic regression analyses of mortality due to sudden death, ascitis, other causes and total mortality

\begin{tabular}{lcccc}
\hline & Degrees of freedom & Sudden death & Ascitis & Other causes \\
\hline Flock & 5 & 0.0027 & 0.4719 & $<.0001$ \\
Light & 1 & 0.0024 & 0.9795 & 0.0021 \\
Flock $\times$ light & 5 & 0.9115 & 0.9990 & 0.0485 \\
Curtain & 1 & 0.5134 & 0.9828 & 0.9983 \\
Flock $\times$ curtain & 5 & 0.9885 & 0.9955 & 0.9983 \\
Light $\times$ curtain & 1 & 0.7839 & 0.9883 & 0.9618 \\
Flock $\times$ light $\times$ curtain & 5 & 0.7846 & 0.5977 & 0.9983 \\
\hline
\end{tabular}


Mortality causes were divided into sudden death, ascitis, other causes and total mortality per flock. There were flock and lighting program effects only on mortality rate due to sudden death and total mortality (Table 3 ).

Whether for live weight or feed conversion ratio, the nearly continuous lighting program was generally better, this program increased sudden death and total mortality rates (Table 4).

These findings are justified by the fact that broilers submitted to continuous lighting present very fast growth rate when young, which may cause cardiac overload, leading to heart attacks, which characterize sudden death, particularly between 30 and 40 days of age, i.e., close to flock removal. Broiler mortality at this age causes significant losses to the producers.

Moreover, the analysis showed that the nearly continuous lighting program promoted 1.48 times more mortality due to sudden death (odds ratio) and 1.34 times more total mortality (Table 5).

There was no difference in mortality due to ascitis, which is in disagreement with the findings of Buys et al. (1998) who reported that intermittent lighting program reduced the incidence of ascitis, and argued that broilers submitted to intermittent lighting program presented significant lower heat production and oxygen consumption during the period of darkness. According to Jaenisch et al. (2005), tissue oxygenation reduction triggers ascitis in broilers, i.e., the higher the bird's oxygen requirements, the higher the chances of ascitis in broilers. Situations that increase bird metabolism, such as low temperatures, increase oxygen requirements and increase mortality due to ascitis (Jaenisch et al., 2001). According to Buyse at al. (1994), oxygen demand has been appointed as the main cause of ascitis, and therefore, the

Table 4 - Mortality rates due to sudden death, ascitis, other causes and total mortality rate as a function of lighting program

\begin{tabular}{lcc}
\hline Mortality causes(\%) & \multicolumn{2}{c}{ Lighting program } \\
\cline { 2 - 3 } & Intermittent & Nearly continuous \\
\hline Sudden death & $2.69 \mathrm{~b}$ & $3.91 \mathrm{a}$ \\
Ascitis & $0.14 \mathrm{a}$ & $0.24 \mathrm{a}$ \\
Other causes & $0.73 \mathrm{a}$ & $0.52 \mathrm{a}$ \\
Total mortality & $4.77 \mathrm{~b}$ & $6.57 \mathrm{a}$ \\
\hline Means followed by different letters in the same row are different $(\mathrm{P} \leq 0.05)$ by the \\
$\chi^{2}$ test.
\end{tabular}

possible lower oxygen consumption of broilers reared under intermittent light may reduce the incidence of ascitis. Classen (1996) observed that broilers submitted to long periods of dark presented better metabolic status. Therefore, the use of continuous or semi-continuous light should be questioned in broiler rearing.

When establishing a lighting program, several factors should be considered, including light intensity. According to Castello et al. (1991), birds can be seen at $0.1 \mathrm{Lx}$, but they do not perform any activity; at $1 \mathrm{Lx}$, birds can be easily managed and they present some activity, and at $5 \mathrm{Lx}$, birds can be perfectly seen, and they fully develop their activities. For this reason, Classen (1996) recommends

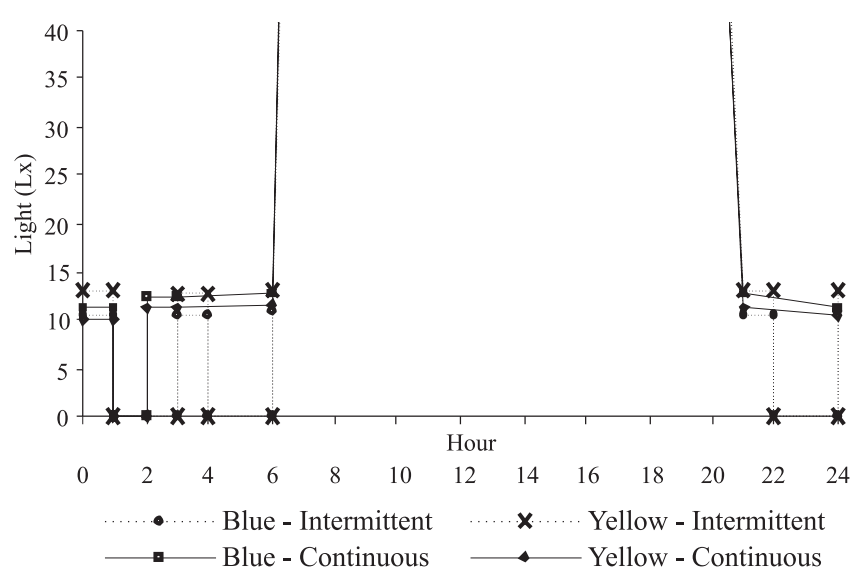

Figure 1 - Average light intensity inside the broiler houses during the 24 hours of the day.

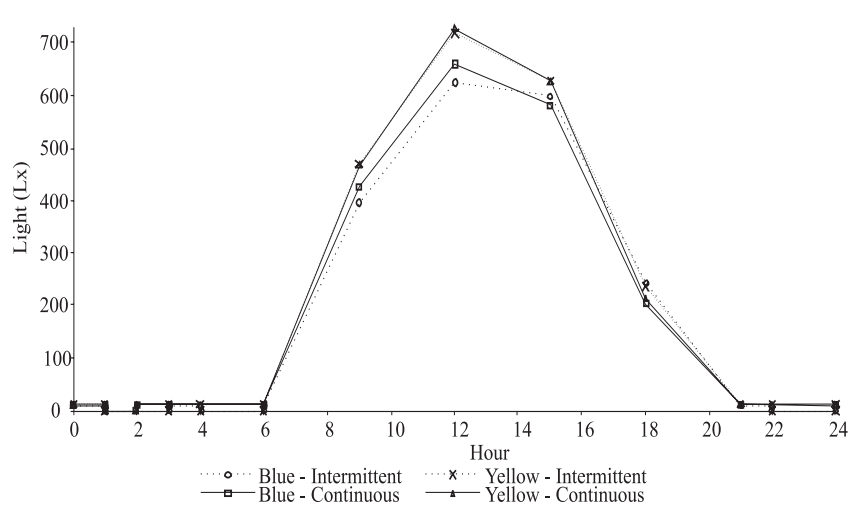

Figure 2 - Light intensity inside the poultry houses during the period of artificial lighting (18:00 to 06:00).

Table 5 - Odds ratio and $\chi^{2}$ test for the contrast between intermittent light and nearly continuous light for sudden death and total mortality rates

\begin{tabular}{lcc}
\hline Contrast & Odds ratio & Pr $>\chi^{2}$ \\
\hline Intermittent $\times$ nearly continuous light (sudden death) & 1.4825 & 0.0024 \\
Intermittent $\times$ nearly continuous light (total mortality) & 1.3437 & 0.0485 \\
\hline
\end{tabular}


Table 6 - Light intensity (Lx) inside the poultry houses as a function of lighting program and curtain color

\begin{tabular}{|c|c|c|c|c|}
\hline \multirow[t]{3}{*}{ Time } & \multicolumn{2}{|c|}{ Intermittent light } & \multicolumn{2}{|c|}{ Nearly continuous light } \\
\hline & Blue curtain & Yellow curtain & Yellow curtain & Blue curtain \\
\hline & House 1 & House 2 & House 3 & House 4 \\
\hline 0 & 10.4 & 13.0 & 10.2 & 11.3 \\
\hline 3 & 10.5 & 12.9 & 11.3 & 12.4 \\
\hline 6 & 10.8 & 13.1 & 11.6 & 12.7 \\
\hline 9 & 397.1 & 468.9 & 465.9 & 425.6 \\
\hline 12 & 624.9 & 718.3 & 728.4 & 659.8 \\
\hline 15 & 599.2 & 627.7 & 626.5 & 581.5 \\
\hline 18 & 242.7 & 234.9 & 212.6 & 204.1 \\
\hline 21 & 10.6 & 13.0 & 11.4 & 12.6 \\
\hline 24 & 10.7 & 13.0 & 10.4 & 11.3 \\
\hline
\end{tabular}

light intensities at the height of the broiler's eye of $20 \mathrm{Lx}$ for 7 days and $5 \mathrm{Lx}$ later on. Sunlight intensity varies daily with sun position, presence of clouds, pollution, and relative air humidity. Moreover, day duration changes according to the position of the Earth relative to the sun (North \& Bell, 1990). In open-sided houses, there is wide variation in light intensity due to sunlight incidence (Figure 2). Because of excessive lighting during the day in open-sided houses, lighting programs should be evaluated for their efficiency during the night.

During the night, broilers received 10 to $13 \mathrm{Lx}$ (Figure 1; Table 6), showing that the two 60W light bulbs distributed inside the house (120 $\mathrm{m}^{2}$ of each house) were sufficient to supply the light intensity required.

North \& Bell (1990) recommend that each Watt cover $0.37 \mathrm{~m}^{2}$ of floor to supply $10 \mathrm{Lx}$ of light, and to take into account lamp height and distribution, considering that light bulbs with more than $60 \mathrm{~W}$ do not provide uniform lighting. Another factor that must be analyzed in the present study is the light intensity obtained in houses with blue curtains. The results showed that curtain color did not influence light intensity inside the houses.

Table 7 - Analysis of variance of the darkling beetle(A. diaperinus) population

\begin{tabular}{lc}
\hline Causes of variation & Pr $>$ F \\
\cline { 2 - 2 } & Larvae + adults \\
\hline Curtain & 0.0235 \\
Light & 0.1328 \\
Curtain $\times$ light & 0.0236 \\
Flock & $<0.0001$ \\
Curtain $\times$ flock & 0.0004 \\
Light $\times$ flock & 0.1147 \\
Curtain $\times$ light $\times$ flock & 0.5643 \\
Collection & $<0.0001$ \\
Curtain $\times$ collection & 0.1583 \\
Light $\times$ collection & 0.0431 \\
Flock $\times$ collection & 0.0029 \\
Curtain $\times$ light $\times$ collection & 0.5711 \\
Light $\times$ flock $\times$ collection & 0.0777 \\
Curtain $\times$ flock $\times$ collection & 0.0777 \\
\hline
\end{tabular}
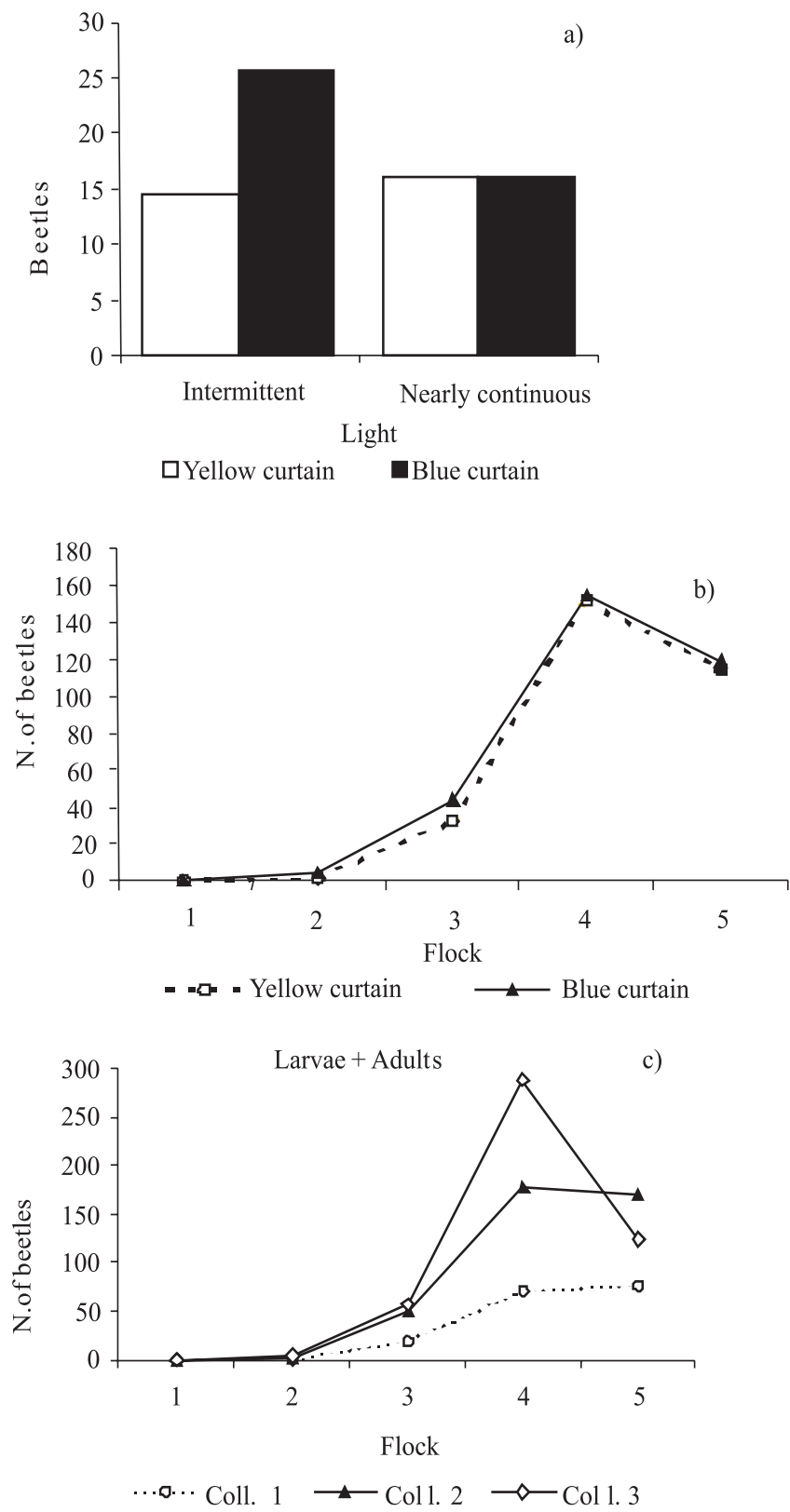

Figure 3 - Darkling beetle counts as a function of curtain color and lighting program (a), curtain color and flock (b) and flock and collection (c) in broiler houses. 
The analysis of the darkling beetle populations indicated significant effects $(\mathrm{P}<0.05)$ of curtain, flock, collection and of the interactions curtain $\times$ light, curtain $\times$ flock, flock $\times$ collection and light $\times$ collection (Table 7). The presence of darkling beetles was significantly higher $(\mathrm{P}<0.05)$ in houses with blue curtains and intermittent lighting program (Figure $3 a$ ).

Despite the significant interaction between flock and curtain color for the incidence of adult darkling beetles and for the sum of adults and larvae, significant differences $(\mathrm{P}<0.05)$ between curtain color were found only in flock 2 for the sum of darkling beetle adults and larvae.

The number of darkling beetles increased as litter was reused, regardless of curtain color, except in flock 5 , where the number of larvae and the sum of larvae and adults decreased (Figure 3b).

After flock 3, collection 1 (pre-housing) presented significantly lower numbers of darkling beetle larvae, whereas for adults, significant differences among collections were observed only in flocks 2 and 3, with collection 3 (42 days, before broiler removal)'s flock 2 presenting higher values when compared with pre-housing and in flock 3, values higher then collection 2 (20 days). The count of the sum of darkling beetle larvae + adults in collection 1 (prehousing) was significantly lower than in the other collections in flocks 2, 3 and 4 (Figure 3c).

Before flock 5 was housed, there was unplanned mechanical interference. A flame-thrower was used against the visible darkling beetles and significantly reduced their incidence. This mechanical action not only interrupted the evolution of the darkling beetle population, but also eradicated them efficiently. Further studies on the use of this practice in litter management among flocks should be carried out to determine its convenience and effectiveness against darkling beetles.

The decision on the lighting program should also take power consumption into consideration, which must be evaluated along with flock performance. In the present study, average electrical energy consumption for intermittent lighting was $44 \mathrm{KWh}$ and $93.16 \mathrm{KWh}$ for the nearly continuous program. This program consumed, in average, 2.12 times more energy than the intermittent lighting program. This was expected, as in the nearly continuous lighting program, lights remained on 12 hours per day, in average, whereas in the intermittent program, only 6 hours. These results show the importance of performing economic analysis because, although the nearly continuous lighting program improves live weight and feed conversion ratio, it causes higher mortality due to sudden death and total mortality, and to consuming more electrical energy.

The economic results of the deterministic models, i.e., using the most probable values (Table 8), showed that, in the first three flocks, the best results, expressed in the lowest production cost, were observed when the intermittent lighting program and yellow curtains were used. This lighting program was first used in June (the first flock was housed on June 24) and last on October 14. On the other hand, for the three last flocks, the best results were obtained when the nearly continuous lighting program and yellow curtains were used.

The cost difference between lighting programs when the same curtain color is used is only due to the placement of a timer that allows changing the lighting program between two periods (winter/spring and summer/fall). The increase in energy demand due to the longer time of lighting in the nearly continuous program must also be considered.

In practical terms, broiler farmers have three different options (Table 8). If the intermittent lighting program and yellow curtains are used during the entire year, the total cost with the six flocks would be $\mathrm{R} \$ 9,510.75$ per metric ton. The second option is to use the nearly continuous lighting program during the entire year, with a cost of $\mathrm{R} \$ 9,506.98$ per metric ton for the six flocks. Finally, a mixed program could be used, alternating an intermittent lighting program and yellow curtains during winter and spring and a nearly

Table 8 - Total production cost (R\$) of one metric ton of broilers according to lighting program/curtain color and flocks

\begin{tabular}{|c|c|c|c|c|c|}
\hline \multirow[t]{2}{*}{ Flock } & \multicolumn{5}{|c|}{ Lighting program/curtain color } \\
\hline & Intermittent/yellow & Intermittent/blue & Nearly continuous/yellow & Nearly continuous/blue & Mixed/yellow \\
\hline 1 & 1505.08 & 1512.23 & 1515.32 & 1527.28 & 1505.08 \\
\hline 3 & 1560.88 & 1604.32 & 1638.11 & 1628.87 & 1560.88 \\
\hline 4 & 1613.70 & 1613.70 & 1586.52 & 1586.52 & 1586.52 \\
\hline 5 & 1620.69 & 1620.36 & 1590.46 & 1612.87 & 1590.46 \\
\hline
\end{tabular}
fall. 
continuous lighting program and yellow curtains during summer and fall, with a cost of $\mathrm{R} \$ 9,369.56$ per metric ton for the six flocks.

The difference between the mixed program and the intermittent program was of $\mathrm{R} \$ 141.20$ per metric ton, whereas it was $\mathrm{R} \$ 137.42$ between the mixed program and the nearly continuous program. The decision should be made as for which program provides the lowest production cost during the entire year. Using the results obtained, and considering an expected average production of 34 metric tons of chicken per flock and an average number of 6.40 flocks produced per year, it is possible to estimate an annual profit with a 1,200 $\mathrm{m}^{2}$ poultry house of $\mathrm{R} \$ 4,983.88$ with the use of the mixed lighting program (intermittent in winter/spring and nearly continuous in summer/fall) and yellow curtains.

The use of the Monte Carlo simulation, with 1,000 simulations, aiming to include risk analysis, confirms the results obtained with the deterministic model. Hence, the use of the mixed model proposed in the present study brings positive results both for poultry companies and for independent and contracted farmers.

\section{Conclusions}

In general, a nearly continuous lighting program and yellow curtains provide better broiler performance. However, this program causes increases in mortality rate and electrical energy consumption. On the other hand, houses with blue curtains and intermittent lighting programs have a higher population of darkling beetles. Finally, the economic analysis including the studied factors supports the recommendation of yellow curtains and intermittent lighting program during winter and spring and nearly continuous lighting program during summer and fall.

\section{References}

ABREU, V.M.N.; ABREU, P.G. Diagnóstico bioclimático para produção de aves no Oeste Paranaense. In: CONGRESSO BRASILEIRO DE ENGENHARIA AGRÍCOLA, 30., 2001. Anais... Foz do Iguaçu: CONBEA, 2001. (CD-ROM).

BUYS, N.; BUYSE, J.; HASSANZADEH-LADMAKHI, M. et al. Intermittent lighting reduces the incidence of ascites in broilers: an interaction with protein content of feed on performance and the endocrine system. Poultry Science, v.77, p.54-61, 1998.

BUYSE, J.; DECUYPERE, E.; MICHELS, H. Intermittent lighting and broiler production. Effect on energy and on nitrogen metabolism. Archiv fur Geflugelkunde, v.58, p.78-83, 1994.

BUYSE, J.; SIMONS, P.C.M.; BOSHOUWERS, F.M.G. et al. Effect of intermittent lighting, light intensity and source on the performance and welfare of broilers. World's Poultry Science Journal, v.52, p.121-130, 1996

CANEVER, M.D.; TALAMINI, D.J.D.; CAMPOS, A.C. et al. Custos de produção do frango de corte no Brasil e Argentina. Concórdia: EMBRAPA-CNPSA, 1996. 37p.

CASTELLO, J.A.; FRANCO, F.; GARCIA, E. Manejo de los pollos. In: _. Producción de carne de pollo. Barcelona: Tecnograf, 1991. p.112-116.

CLASSEN, H.L. Principios sobre el manejo de luz em pollos de engorde. Avicultura Professional, v.14, n.2, p.21-27, 1996

FUSSEL, L.W.; DIPLOMATE, M.A.M.; ROSSI, A. Lighting programs and Cobb 500 broiler performance. Technical Focus, v.1, p.1-4, 2003.

JAENISCH, F.R.F.; CUCCHI, V.; BITENCOURT, G. et al Histopatologia em pulmões e corações de frangos suplementados com oxigênio durante a fase de incubação. Ciência Rural, v.35, n.3, p.633-638, 2005.

JAENISCH, F.R.F.; AVILA, V.S.; MAZZUCO, H. et al. Síndrome da hipertensão pulmonar: a ascite em frangos de corte. Concórdia: Embrapa Suínos e Aves, 2001. 16p. (Documentos, 27).

MORAES, D.T.; GONZALES, M.L.; BAIÃO, N.C. et al. Efeito dos programas de luz sobre o comportamento alimentar em frangos de corte. Revista Brasileira de Ciência Avícola, v.9, p.12, 2007 (supl. 8).

NORTH, M.O.; BELL, D. Lighting management. In: --. Commercial chicken production manual. 4.ed. London: Chapman \& Hall, 1990. p.407-431.

RENDEN, J.A.; MORAN JUNIOR, E.T.; KINCAID, S.A. Lighting programs for broilers that reduce leg problems without loss of performance or yield. Poultry Science, v.75, p.1345-1350, 1996.

RESENDE FILHO, M.A.; BRAGA, M.J.; RODRIGUES, R.V. Sistemas de terminação em confinamento: perspectivas para dinamização da cadeia produtiva da carne bovina em Minas Gerais. Revista Brasileira de Economia, v.55, n.1, p.105-129, 2001.

RUTZ, F.; ROLL, V.F.B.; XAVIER, E. G. Manejo de luz para frangos e reprodutoras. In: CONFÊRENCIA APINCO DE CIÊNCIA E TECNOLOGIA AVÍCOLAS, 2000, Campinas. Anais.. Campinas: FACTA, 2000. p.213-240.

RUTZ, F.; BERMUDEZ, V.L. Fundamentos de um programa de luz para frangos de corte. In: MENDES, A.A.; NAAS, I.A.; MACARI, M. (Eds.) Produção de frangos de corte. Campinas: FACTA, 2004. p.157-168.

SAFRIT, R.D.; AXTELL, R.C. Evaluations of sampling methods for darkling beetles (Alphitobius diaperinus) in the litter of turkey and broiler houses. Poultry Science, v.63, p.2368-2375, 1984.

SANTOS FILHO, J.I.; CANEVER, M.D.; CHIUCHETTA, O. et al. Aspectos econômicos e viabilidade da criação de frangos nos sistemas convencional e automatizado. In: SIMPÓSIO INTERNACIONAL DE AMBIÊNCIA E SISTEMA DE PRODUÇÃO AVÍCOLA, 1998, Concórdia. Anais... Concórdia: Embrapa Suínos e Aves, 1998. v.1. p.1-13.

STATISTICAL ANALYSES SYSTEM - SAS. System for Microsoft Windows: release 9,1. Cary: 2002-2003. (1 CD-ROM).

XAVIER, L.H. Modelos univariado e multivariado para análise de medidas repetidas e verificação da acurácia do modelo univariado por meio de simulação. 2000. 91f Dissertação (Mestrado em Agronomia) - Escola Superior de Agricultura "Luiz de Queiroz”, Piracicaba.

ZUBAIR, A.K.; LEESON, S. Compensatory growth in the broiler chicken: a review. World's Poultry Science Journal, v.52, n.2, p.189-201, 1996. 